\title{
Microwave assisted synthesis of some novel Flurbiprofen hydrazide- hydrazones as anti-HCV NS5B and anticancer agents
}

\author{
Sevil Aydın, Neerja Kaushik-Basu², Payal Arora², Amartya Basu², Daniel Brian Nichols²,

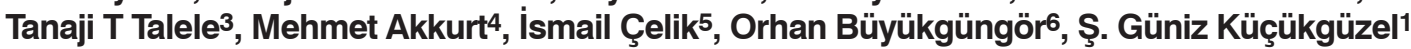

\begin{abstract}
The synthesis of a new series of flurbiprofen hydrazide-hydrazones using microwave assisted reactions is described. Substituted aldehydes were condensed with flurbiprofen hydrazide by microwave irradiation to corresponding hydrazones. Synthesis of N'-[(4-bromothiophen-2-yl)methylidene]-2-(2-fluorobiphenyl-4-yl) propanehydrazide (30) employing microwave assisted process resulted in higher yields, in faster time and with less chemical waste compared to traditional techniques. (2-fluorobiphenyl-4-yl)- $N^{\prime}$ (phenylmethylidene)propanehydrazide (3p) and N'-[(2-chloro-6-fluorophenyl) methylidene]2-(2-fluorobiphenyl-4-yl)propanehydrazide (3s) inhibited the growth of a leukemia cancer cell line HL-60 (TB) by $66.37 \%$ and an ovarian cancer cell line OVCAR-4 by $77.34 \%$ (single dose, $10 \mu \mathrm{M})$, respectively at the National Cancer Institute $(\mathrm{NCl})$, but had no significant effect on a panel of sixty human tumor cell lines. Flurbiprofen hydrazide-hydrazones were weak inhibitors of hepatitis C virus NS5B polymerase activity with N'-[(5-ethylfuran-2-yl) methylidene]-2-(2-fluorobiphenyl-4-yl)propanehydrazide $(3 \mathrm{~m})$ being the most active of this series. Binding mode investigations of compound $3 \mathrm{~m}$ suggested that allosteric pocket (AP)$B$ may be the potential binding site for flurbiprofen hydrazones and these results will also assist in further derivatization of $3 \mathrm{~m}$ using the green chemistry approach and improve the potency of S-flurbiprofen hydrazide-hydrazones.
\end{abstract}

KEY WORDS: anticancer activity, E-Z isomerism, flurbiprofen, hepatitis C NS5B polymerase, hydrazide-hydrazone, microwave.

\section{INTRODUCTION}

Flurbiprofen, a well characterized non-steroidal anti-inflammatory drug (NSAID) has emerged as a potential anticancer agent due to its anti-proliferative properties in several cell lines and its ability to supress tumor formation (1-6). Hydrazidehydrazones and their derivatives are versatile molecules with broad spectrum biological activities (7-10). Previously, we had synthesized a panel of flurbiprofen hydrazide-hydrazone derivatives and observed that they inhibited hepatitis $\mathrm{C}$ virus (HCV) NS5B RNA-dependent RNA polymerase (RdRp) activity by $20-50 \%$ at $200 \mu \mathrm{M}$ concentration (11). Therefore, we undertook molecu- lar modification and synthesized newer flurbiprofen hydrazide-hydrazone derivatives to improve their inhibitory potency on HCV NS5B.

Microwave assisted reactions are alternative methods to traditional techniques of chemical synthesis (12). Microwave assisted synthesis has several advantages over traditional means including higher yields and time and energy saving. Further, this method requires much less solvent to generate compounds, thus making this green chemistry technique more environmentally friendly. Given the advantages of microwave assisted synthesis of compounds, the application
AFFILIATIONS

${ }^{1}$ Marmara University, Faculty of Pharmacy, Department of Pharmaceutical Chemistry, İstanbul, Turkey

2UMDNJ-New Jersey Medical School, Department of Biochemistry and Molecular Biology, Newark, USA

3St. John's University, Department of

Pharmaceutical Sciences, College of Pharmacy and Allied Health Professions, Jamaica, NY 11439

4Erciyes University, Department of Physics Faculty of Arts and Sciences, Kayseri, Turkey ${ }^{5}$ Cumhuriyet University, Department of Physics Faculty of Arts and Sciences, Sivas, Turkey ${ }^{6}$ Ondokuz Mayıs University, Department of Physics Faculty of Arts and Sciences, Samsun, Turkey

\section{CORRESPONDENCE}

Ş.Güniz Küçükgüzel

E-mail: gkucukguzel@marmara.edu.tr Received: 26.09.2012

Revision: 22.11.2012 
of this technology in medicinal chemistry has the potential to rapidly generate chemical libraries for the purpose of screening molecules for drug discovery (13).

In this study, we synthesized a series of flurbiprofen hydrazide-hydrazone derivatives using microwave assisted reactions. We obtained compounds at higher yields, in faster time, and with less chemical waste than when using traditional techniques. The compounds generated were evaluated for both their anti-HCV NS5B polymerase and anticancer activities in 60 human cancer cell lines.

\section{EXPERIMENTAL Chemistry}

Flurbiprofen was generously provided by Sanovel Pharmaceuticals (Istanbul, Turkey). Substituted aldehydes were purchased from Fluka and Aldrich. All other chemicals were purchased from Merck. Melting points were taken on Schmelzpunktbestimmer SMP II apparatus and uncorrected. Elemental analyses were performed on VarioMICRO V1.5.7. instrument. UV spectra were recorded on Shimadzu UV-1700 spectrophotometer $(1 \mathrm{mg} / 100 \mathrm{~mL} \mathrm{MeOH})$. IR spectra were run on Schimadzu FTIR-8400S spectrophotometer. ${ }^{1} \mathrm{H}-\mathrm{NMR}$ and ${ }^{13} \mathrm{C}-\mathrm{NMR}$ spectra were obtained on a Bruker AVANCE-DPX 400 instrument. EI-Mass spectra were performed using Agilent 1100 LC-MS instrument. All experiments under microwave irradiation were carried out in household microwave oven model MW 570 manufactured by Kenwood Corporation (maximum power output of 900W).

Single crystal X-ray crystallography was carried out with high levels of accuracy. Data collection was carried out with STOE IPDS 2 diffractomer. $\mathrm{H}$ atoms were positioned geometrically with $\mathrm{N}-\mathrm{H}=0.86 \AA, \mathrm{C}-\mathrm{H}=0.93-0.98 \AA$ and refined using a riding model with $\mathrm{Uiso}(\mathrm{H})=1.2$ or $1.5 \mathrm{Ueq}(\mathrm{C}, \mathrm{N})$. Data collection: X-AREA (14). Cell refinement: X-AREA. Data reduction: X-RED32. Program(s) used to solve structure: SIR97 (15). Program(s) used to refine structure: SHELXL97 (16). Molecular graphics: ORTEP-3 (17). Software used to prepare material for publication: WinGX (18).

Preparation of Methyl 2-(2-fluorobiphenyl-4-yl)propanoate (1) and 2-(2-fluorobiphenyl-4-yl)propanehydrazide (2)

Flurbiprofen $(0.01 \mathrm{~mol})$ and methanol $(30 \mathrm{~mL})$ were refluxed for $3 \mathrm{~h}$ in a few drops of concentrated sulfuric acid. After cooling, the mixture was neutralized with $5 \%$ aqueous $\mathrm{NaHCO}_{3}$, extracted twice with ether, and the organic layer was dried over $\mathrm{Na}_{2} \mathrm{SO}_{4}$. Evaporation of the solvent gave compound 1 as an oily product and was used for the next step without further purification.

Compound 1 (0.01 mol) and hydrazine-hydrate (99\%, $4 \mathrm{~mL})$ were refluxed in $20 \mathrm{~mL}$ ethanol for $2 \mathrm{~h}$ and allowed to cool. The solid precipitate was washed with water, dried and recrystallised twice from ethanol to give compound 2. m.p $101^{\circ} \mathrm{C}$ (m.p. $96^{\circ} \mathrm{C}$ in ref. 19).

General procedure for microwave assisted synthesis of 2-(2-fluorobiphenyl-4-yl)-[(nonsubstituted/substituted furyl/phenyl/pyridyl/thienyl)methylidene]propanehydrazides (3a-u)

A solution of $2(0.0025 \mathrm{~mol})$ in $5 \mathrm{~mL}$ ethanol and an appropriate aldehyde $(0.0025 \mathrm{~mol})$ were heated under microwave irra- diation (270 W) for 3-5 min to yield compounds 3a-u. The reaction medium was allowed to cool at room temperature and the precipitate obtained was filtered, washed with water and dried. The product was then recrystallised twice from ethanol.

Synthesis of $N^{\prime}$-[(4-bromothiophen-2-yl)methylidene]-2-(2fluorobiphenyl-4-yl) propanehydrazide (3o) by conventional method

2-(2-Fluorobiphenyl-4-yl)propanehydrazide (2) (0.0025 mol) was dissolved in boiling absolute ethanol. Equimolar amounts of the 4-bromothiophen 2-carboxaldehyde was added and refluxed for $2 \mathrm{~h}$. The flask content was allowed to cool, and the filtered and dried precipitates were recrystallized from ethanol.

\section{2-(2-fluorobiphenyl-4-yl)-N'-[(pyridin-4-yl)methylidene]} propanehydrazide (3a)

Yield 84\%; m.p $114{ }^{\circ} \mathrm{C}$; UV (MeOH) $\lambda_{\max }$ nm: 287, 248, 203; IR ( $\mathrm{cm}^{-1}$ ): 3500 (ethanol -OH str ); 3178 (N-H str of amide), 1683 ( $\mathrm{C}=\mathrm{O}$ str of amide), 1624 ( $\mathrm{C}=\mathrm{N}$ str of hydrazone); ${ }^{1} \mathrm{H}-\mathrm{NMR}$ $\left(\mathrm{DMSO}_{6}, 400 \mathrm{MHz}\right) \delta$ (ppm): $1.06\left(3 \mathrm{H}, \mathrm{t}\right.$, flur. $\left.\mathrm{CH}_{3}\right), 1.45(3 \mathrm{H}$, $\mathrm{t}$, ethanol $\left.-\mathrm{CH}_{3}\right), 3.45\left(2 \mathrm{H}, \mathrm{m}\right.$, ethanol $\left.-\mathrm{CH}_{2}\right), 3.80$ and $4.77(1 \mathrm{H}$, qq, flur. $\mathrm{CH}), 4.35(1 \mathrm{H}, \mathrm{q}$, ethanol $-\mathrm{OH}), 7.34-7.67(12 \mathrm{H}, \mathrm{m}, \mathrm{Ar}-$ $\mathrm{H}), 7.93$ and $8.22(1 \mathrm{H}, \mathrm{ss}, \mathrm{CH}=\mathrm{N}), 11.66$ and $11.74(1 \mathrm{H}, \mathrm{ss}, \mathrm{NH})$. Anal. Calcd for $\mathrm{C}_{21} \mathrm{H}_{18} \mathrm{FN}_{3} \mathrm{O} . \mathrm{C}_{2} \mathrm{H}_{5} \mathrm{OH}$ : C, 70.21; H, 6.15; N, 10.68. Found: C, 69.28; H, 5.91; N, 10.76.

\section{2-(2-fluorobiphenyl-4-yl)-N'-[(pyridin-3-yl)methylidene] propanehydrazide $(3 b)$}

Yield 99\%; m.p $154{ }^{\circ} \mathrm{C}$; UV (MeOH) $\lambda_{\max }$ nm: 279, 249, 204; IR ( $\left.\mathrm{cm}^{-1}\right)$ : 3117 (N-H str of amide), 1688 (C=O str of amide), 1622 (C=N str of hydrazone); ${ }^{1} \mathrm{H}-\mathrm{NMR}\left(\mathrm{DMSO}_{6}, 400 \mathrm{MHz}\right) \delta$ (ppm): 1.45 (3H, t, flur. $\left.\mathrm{CH}_{3}\right), 3.79$ and $4.77(1 \mathrm{H}, \mathrm{qq}$, flur. $\mathrm{CH})$, 7.29-8.16 (12H, m, Ar-H), 8.01 and $8.30(1 \mathrm{H}, \mathrm{ss}, \mathrm{CH}=\mathrm{N}), 11.56$ and $11.77(1 \mathrm{H}, \mathrm{ss}, \mathrm{NH})$. Anal. Calcd for $\mathrm{C}_{21} \mathrm{H}_{18} \mathrm{FN}_{3} \mathrm{O}: \mathrm{C}, 72.61$; H, 5.22; N, 12.10. Found: C, 72.26; H, 5.18; N, 11.85 .

\section{2-(2-fluorobiphenyl-4-yl)-N'-[(pyridin-2-yl)methylidene] propanehydrazide $(3 \mathrm{c})$}

Yield 96\%; m.p $180{ }^{\circ} \mathrm{C}$; UV (MeOH) $\lambda_{\max }$ nm: 293, 249; IR (cm 1): 3186 (N-H str of amide), 1663 (C=O str of amide), 1647 (C=N str of hydrazone); ${ }^{1} \mathrm{H}-\mathrm{NMR}$ (DMSO- $\left.\mathrm{d}_{6}, 400 \mathrm{MHz}\right) \delta$ (ppm): $1.46\left(3 \mathrm{H}, \mathrm{t}\right.$, flur. $\left.\mathrm{CH}_{3}\right), 3.79$ and $4.79(1 \mathrm{H}, \mathrm{qq}$, flur. $\mathrm{CH}), 7.29-8.60$ $(12 \mathrm{H}, \mathrm{m}, \mathrm{Ar}-\mathrm{H}), 8.01$ and $8.02(1 \mathrm{H}, \mathrm{ss}, \mathrm{CH}=\mathrm{N}), 11.61$ and 11.82 $(1 \mathrm{H}, \mathrm{ss}, \mathrm{NH})$. Anal. Calcd for $\mathrm{C}_{21} \mathrm{H}_{18} \mathrm{FN}_{3} \mathrm{O}: \mathrm{C}, 72.61 ; \mathrm{H}, 5.22 ; \mathrm{N}$, 12.10. Found: C, 72.50; H, 5.15; N, 12.07 .

\section{2-(2-fluorobiphenyl-4-yl)- $N^{\prime}$-[(thiophen-2-yl)methylidene] propanehydrazide (3d)}

Yield 83\%; m.p $193{ }^{\circ} \mathrm{C}$; UV (MeOH) $\lambda_{\max }$ nm: 309, 249, 202; IR $\left(\mathrm{cm}^{-1}\right): 3184$ (N-H str of amide), 1660 (C=O str of amide), 1639 (C=N str of hydrazone); ${ }^{1} \mathrm{H}-\mathrm{NMR}\left(\mathrm{DMSO}_{6}, 400 \mathrm{MHz}\right) \delta$ (ppm): $1.43\left(3 \mathrm{H}, \mathrm{t}\right.$, flur. $\left.\mathrm{CH}_{3}\right), 3.74$ and $4.60(1 \mathrm{H}, \mathrm{qq}$, flur. $\mathrm{CH})$, 7.09-7.65 (11H, m, Ar-H), 8.12 and $8.43(1 \mathrm{H}, \mathrm{ss}, \mathrm{CH}=\mathrm{N}), 11.38$ and $11.55(1 \mathrm{H}, \mathrm{ss}, \mathrm{NH})$. Anal. Calcd for $\mathrm{C}_{20} \mathrm{H}_{17} \mathrm{FN}_{2} \mathrm{OS}$ : C, 68.16; H, 4.86; N, 7.95. Found: C, 68.10; H, 4.76; N, 7.95.

2-(2-fluorobiphenyl-4-yl)- $N^{\prime}$-[(3-methylthiophen-2-yl)methylidene]propanehydrazide (3e)

Yield 88\%; m.p 184-185 ${ }^{\circ} \mathrm{C}$; UV (MeOH) $\lambda_{\max }$ nm: 312, 277, 248; IR (cm-1): 3198 (N-H str of amide), 1683 (C=O str of amide), 
1624 (C=N str of hydrazone); ${ }^{1} \mathrm{H}-\mathrm{NMR}\left(\mathrm{DMSO}-\mathrm{d}_{6}, 400 \mathrm{MHz}\right) \delta$ (ppm): $1.43\left(3 \mathrm{H}, \mathrm{t}\right.$, flur. $\left.\mathrm{CH}_{3}\right), 2.25$ and $2.29(3 \mathrm{H}$, ss, thiophene $\left.\mathrm{CH}_{3}\right), 3.73$ and $4.59(1 \mathrm{H}, \mathrm{qq}$, flur. $\mathrm{CH}), 6.93-7.54(10 \mathrm{H}, \mathrm{m}, \mathrm{Ar}-$ $\mathrm{H}), 8.17$ and $8.46(1 \mathrm{H}, \mathrm{ss}, \mathrm{CH}=\mathrm{N}), 11.23$ and $11.49(1 \mathrm{H}, \mathrm{ss}, \mathrm{NH})$. Anal. Calcd for $\mathrm{C}_{21} \mathrm{H}_{19} \mathrm{FN}_{2} \mathrm{OS}$ : C, 68.83; $\mathrm{H}, 5.23 ; \mathrm{N}, 7.64$. Found: C, 69.03; H, 5.10; N, 7.95.

2-(2-fluorobiphenyl-4-yl)- $N^{\prime}$-[(5-methylthiophen-2-yl)methylidene]propanehydrazide (3f)

Yield 93\%; m.p 191-192 oC; UV (MeOH) $\lambda_{\max }$ nm: 316, 249; IR $\left(\mathrm{cm}^{-1}\right)$ : 3184 (N-H str of amide), 1643 (C=O str of amide), 1593 ( $\mathrm{C}=\mathrm{N}$ str of hydrazone); ${ }^{1} \mathrm{H}-\mathrm{NMR}$ (DMSO- $\left.d_{6}, 400 \mathrm{MHz}\right) \delta$ (ppm): $1.42\left(3 \mathrm{H}, \mathrm{t}\right.$, flur. $\left.\mathrm{CH}_{3}\right), 2.45$ and $2.46(3 \mathrm{H}$, ss, thiophene $\left.\mathrm{CH}_{3}\right), 3.73$ and $4.58(1 \mathrm{H}, \mathrm{qq}$, flur. $\mathrm{CH}), 6.79-7.54(10 \mathrm{H}, \mathrm{m}, \mathrm{Ar}-$ $\mathrm{H}), 8.02$ and $8.33(1 \mathrm{H}, \mathrm{ss}, \mathrm{CH}=\mathrm{N}), 11.30$ and $11.47(1 \mathrm{H}, \mathrm{ss}, \mathrm{NH})$. Anal. Calcd for $\mathrm{C}_{21} \mathrm{H}_{19} \mathrm{FN}_{2} \mathrm{OS}$ : C, 68.83; $\mathrm{H}, 5.23 ; \mathrm{N}, 7.64$. Found: C, 68.48; H, 4.44; N, 7.67.

2-(2-fluorobiphenyl-4-yl)-N'-[(5-ethylthiophen-2-yl)methylidene]propanehydrazide $(3 \mathrm{~g})$

Yield 98\%; m.p 160ㄷ; UV (MeOH) $\lambda_{\max }$ nm: 317, 248; IR (cm1): 3184 (N-H str of amide), 1641 (C=O str of amide) 1595 (C=N str of hydrazone); ${ }^{1} \mathrm{H}-\mathrm{NMR}$ (DMSO- $\left.\mathrm{d}_{6}, 400 \mathrm{MHz}\right) \delta$ (ppm): $1.24\left(3 \mathrm{H}, \mathrm{q}\right.$, thiophene $\left.\mathrm{CH}_{3}\right), 1.43\left(3 \mathrm{H}, \mathrm{q}\right.$, flur. $\left.\mathrm{CH}_{3}\right), 2.81(2 \mathrm{H}$, $\mathrm{m}$, thiophene $\left.\mathrm{CH}_{2}\right), 3.73$ and $4.59(1 \mathrm{H}, \mathrm{qq}$, flur. $\mathrm{CH}), 6.82-7.54$ $(10 \mathrm{H}, \mathrm{m}, \mathrm{Ar}-\mathrm{H}), 8.04$ and $8.35(1 \mathrm{H}, \mathrm{ss}, \mathrm{CH}=\mathrm{N}), 11.29$ and 11.46 $(1 \mathrm{H}, \mathrm{ss}, \mathrm{NH})$. Anal. Calcd for $\mathrm{C}_{22} \mathrm{H}_{21} \mathrm{FN}_{2} \mathrm{OS}$ : C, 69.45; H, 5.56; N, 7.36. Found: C, 69.61; H, 5.43; N, 7.34.

2-(2-fluorobiphenyl-4-yl)- $N^{\prime}$-[(5-nitrothiophen-2-yl)methylidene]propanehydrazide (3h)

Yield 89\%; m.p 179॰C; UV (MeOH) $\lambda_{\max }$ nm: 371, 250; IR (cm1): 3176 (N-H str of amide), 1654 (C=O str of amide), 1622 (C=N str of hydrazone); ${ }^{1} \mathrm{H}-\mathrm{NMR}$ (DMSO-d $\left.{ }_{6}, 400 \mathrm{MHz}\right) \delta$ (ppm): $1.44\left(3 \mathrm{H}, \mathrm{q}\right.$, flur. $\left.\mathrm{CH}_{3}\right), 3.79$ and $4.61(1 \mathrm{H}, \mathrm{qq}$, flur. $\mathrm{CH}), 7.23-$ $7.54(10 \mathrm{H}, \mathrm{m}, \mathrm{Ar}-\mathrm{H}), 8.09$ and $8.48(1 \mathrm{H}, \mathrm{ss}, \mathrm{CH}=\mathrm{N}), 11.81$ and $11.96(1 \mathrm{H}, \mathrm{ss}, \mathrm{NH})$. Anal. Calcd for $\mathrm{C}_{20} \mathrm{H}_{16} \mathrm{FN}_{3} \mathrm{O}_{3} \mathrm{~S}$ : C, 60.44; $\mathrm{H}$, 4.06; N, 10.57. Found: C, 60.75; H, 3.92; N, 10.59 .

\section{2-(2-fluorobiphenyl-4-yl)- $N^{\prime}$-[(furan-2-yl)methylidene]pro- panehydrazide (3i)}

Yield 95\%; m.p 197\%C; UV (MeOH) $\lambda_{\max }$ nm: 299, 247, 202.5; IR $\left(\mathrm{cm}^{-1}\right)$ : 3190 (N-H str of amide), 1641 (C=O str of amide) 1622 (C=N str of hydrazone); ${ }^{1} \mathrm{H}-\mathrm{NMR}\left(\mathrm{DMSO}_{-} \mathrm{d}_{6}, 400 \mathrm{MHz}\right) \delta$ (ppm): 1.34 (3H, t, flur. $\left.\mathrm{CH}_{3}\right), 3.64$ and $4.59(1 \mathrm{H}, \mathrm{qq}$, flur. $\mathrm{CH})$, 6.50-7.74 $(11 \mathrm{H}, \mathrm{m}, \mathrm{Ar}-\mathrm{H}), 7.77$ and $8.01(1 \mathrm{H}, \mathrm{ss}, \mathrm{CH}=\mathrm{N}), 11.25$ and $11.43(1 \mathrm{H}$, ss, $\mathrm{NH})$. Anal. Calcd for $\mathrm{C}_{20} \mathrm{H}_{17} \mathrm{FN}_{2} \mathrm{O}_{2}$ : C, 71.42; H, 5.09; N, 8.33. Found: C, 71.18; H, 4.99; N, 8.24.

\section{2-(2-fluorobiphenyl-4-yl)-N'-[(furan-3-yl)methylidene]pro- panehydrazide $(3 \mathbf{j})$}

Yield 94\%; m.p 156 ${ }^{\circ} \mathrm{C}$; UV (MeOH) $\lambda_{\max }$ nm: 274, 269, 256; IR $\left(\mathrm{cm}^{-1}\right)$ : 3178 (N-H str of amide), 1654 (C=O str of amide), 1626 (C=N str of hydrazone); ${ }^{1} \mathrm{H}-\mathrm{NMR}\left(\mathrm{DMSO}_{-} \mathrm{d}_{6}, 400 \mathrm{MHz}\right) \delta$ (ppm): $1.43\left(3 \mathrm{H}, \mathrm{q}\right.$, flur. $\left.\mathrm{CH}_{3}\right), 3.73$ and $4.69(1 \mathrm{H}, \mathrm{qq}$, flur. $\mathrm{CH})$, 6.73-7.54 (11H, m, Ar-H), 8.11 and $8.17(1 \mathrm{H}, \mathrm{ss}, \mathrm{CH}=\mathrm{N}), 11.28$ and $11.46(1 \mathrm{H}$, ss, $\mathrm{NH})$. Anal. Calcd for $\mathrm{C}_{20} \mathrm{H}_{17} \mathrm{FN}_{2} \mathrm{O}_{2}: \mathrm{C}, 71.42$; H, 5.09; N, 8.33. Found: C, 71.39; H, 4.89; N, 8.33.

$N^{\prime}$-[(5-bromofuran-2-yl)methylidene]-2-(2-fluorobiphenyl4-yl)propanehydrazide (3k)
Yield 88\%; m.p 179-182 ${ }^{\circ} \mathrm{C}$; UV (MeOH) $\lambda_{\max }$ nm: 308, 246; IR ( $\left.\mathrm{cm}^{-1}\right)$ : 3211 (N-H str of amide), 1651 (C=O str of amide) 1622 (C=N str of hydrazone); ${ }^{1} \mathrm{H}-\mathrm{NMR}$ (DMSO-d $\left.{ }_{6}, 400 \mathrm{MHz}\right) \delta$ (ppm): $1.43\left(3 \mathrm{H}, \mathrm{q}\right.$, flur. $\left.\mathrm{CH}_{3}\right), 3.74$ and $4.65(1 \mathrm{H}, \mathrm{qq}$, flur. $\mathrm{CH})$, 6.73-7.54 (10H, m, Ar-H), 7.77 and $8.02(1 \mathrm{H}, \mathrm{ss}, \mathrm{CH}=\mathrm{N}), 11.42$ and $11.60(1 \mathrm{H}, \mathrm{ss}, \mathrm{NH})$. Anal. Calcd for $\mathrm{C}_{20} \mathrm{H}_{16} \mathrm{BrFN}_{2} \mathrm{O}_{2}: \mathrm{C}$, 57.85; H, 3.88; N, 6.75. Found: C, 58.40; H, 3.71; N, 6.81.

\section{$N^{\prime}$-[(5-chlorofuran-2-yl)methylidene]-2-(2-fluorobiphenyl-} 4-yl)propanehydrazide (31)

Yield 96\%; m.p 182-184 ${ }^{\circ} \mathrm{C}$; UV (MeOH) $\lambda_{\max }$ nm: 305, 246; IR (cm-1): 3213 (N-H str of amide), 1653 (C=O str of amide), 1622 (C=N str of hydrazone); ${ }^{1} \mathrm{H}-\mathrm{NMR}\left(\mathrm{DMSO}_{6}, 400 \mathrm{MHz}\right) \delta$ (ppm): $1.43\left(3 \mathrm{H}, \mathrm{t}\right.$, flur. $\left.\mathrm{CH}_{3}\right), 3.75$ and $4.65(1 \mathrm{H}, \mathrm{qq}$, flur. $\mathrm{CH})$, 6.64-7.54 (10H, m, Ar-H), 7.77 and $8.02(1 \mathrm{H}, \mathrm{ss}, \mathrm{CH}=\mathrm{N}), 11.41$ and $11.60(1 \mathrm{H}, \mathrm{ss}, \mathrm{NH}) .{ }^{13} \mathrm{C}-\mathrm{NMR}\left(\mathrm{DMSO}_{\mathrm{d}}\right) \delta(\mathrm{ppm}): 18.35$ and 18.72 (flur. $\mathrm{CH}_{3}$ ), 39.79 and 40.00 (flur. $\mathrm{CH}$ ), 115.28-137.73 (aromatic C), 149.56 and $149.64(\mathrm{CH}=\mathrm{N}), 169.73$ and 174.77 $(\mathrm{C}=\mathrm{O})$. Anal. Calcd. for $\mathrm{C}_{20} \mathrm{H}_{16} \mathrm{ClFN}_{2} \mathrm{O}_{2}: \mathrm{C}, 64.78 ; \mathrm{H}, 4.35 ; \mathrm{N}$, 7.55. Found: C, 64.64; H, 4.20; N, 7.55.

$N^{\prime}$-[(5-ethylfuran-2-yl)methylidene]-2-(2-fluorobiphenyl4-yl)propanehydrazide $(3 \mathrm{~m})$

Yield 99\%; m.p $149^{\circ} \mathrm{C}$; UV (MeOH) $\lambda_{\max }$ nm: 305, 245; IR (cm1): 3209 (N-H str of amide), 1651 (C=O str of amide), 1624 (C=N str of hydrazone); ${ }^{1} \mathrm{H}-\mathrm{NMR}$ (DMSO- $\left.\mathrm{d}_{6}, 400 \mathrm{MHz}\right) \delta$ (ppm): $1.20\left(3 \mathrm{H}, \mathrm{m}\right.$, furan $\left.\mathrm{CH}_{3}\right), 1.43\left(3 \mathrm{H}, \mathrm{t}\right.$, flur. $\left.\mathrm{CH}_{3}\right), 2.67(2 \mathrm{H}, \mathrm{m}$, furan $\left.\mathrm{CH}_{2}\right), 3.73$ and $4.64(1 \mathrm{H}, \mathrm{qq}$, flur. $\mathrm{CH}), 6.24-7.54(10 \mathrm{H}, \mathrm{m}$, Ar-H), 7.76 and $8.00(1 \mathrm{H}, \mathrm{ss}, \mathrm{CH}=\mathrm{N}), 11.27$ and $11.45(1 \mathrm{H}, \mathrm{ss}$, $\mathrm{NH})$. Anal. Calcd for $\mathrm{C}_{22} \mathrm{H}_{21} \mathrm{FN}_{2} \mathrm{O}_{2}$ : C, 72.51; H, 5.81; N, 7.69. Found: C, 72.67; H, 5.63; N, 7.73 .

$N^{\prime}$-[[5-(2-nitrophenyl)furan-2-yl]methylidene]-2-(2-fluorobiphenyl-4-yl)propanehydrazide (3n)

Yield 95\%; m.p $165^{\circ} \mathrm{C}$; UV (MeOH) $\lambda_{\max }$ nm: 322, 244, 202; IR ( $\left.\mathrm{cm}^{-1}\right)$ : 3300 (N-H str of amide), 1658 (C=O str of amide), 1616 (C=N str of hydrazone); ${ }^{1} \mathrm{H}-\mathrm{NMR}\left(\mathrm{DMSO}_{6}, 400 \mathrm{MHz}\right) \delta$ (ppm): $1.44\left(3 \mathrm{H}, \mathrm{q}\right.$, flur. $\left.\mathrm{CH}_{3}\right), 3.74$ and $4.72(1 \mathrm{H}, \mathrm{qq}$, flur. $\mathrm{CH})$, 7.01-7.54 (14H, m, Ar-H), 7.81 and $8.15(1 \mathrm{H}, \mathrm{ss}, \mathrm{CH}=\mathrm{N}), 11.44$ and $11.61(1 \mathrm{H}, \mathrm{ss}, \mathrm{NH})$. Anal. Calcd for $\mathrm{C}_{26} \mathrm{H}_{20} \mathrm{FN}_{3} \mathrm{O}_{4}$ : C, 68.26; H, 4.41; N, 9.19. Found: C, 68.45; H, 4.25; N, 9.21.

$N^{\prime}$-[(4-bromothiophen-2-yl)methylidene]-2-(2-fluorobiphenyl-4-yl)propanehydrazide (3o)

Yield $84 \%$; m.p $205^{\circ} \mathrm{C}$; UV (MeOH) $\lambda_{\max } \mathrm{nm}: 314,249,204$; IR (cm1): 3167 (N-H str of amide), 1670 (C=O str of amide), 1622 (C=N str of hydrazone); ${ }^{1} \mathrm{H}-\mathrm{NMR}$ (DMSO-d $\left.{ }_{6}, 400 \mathrm{MHz}\right) \delta(\mathrm{ppm}): 1.43(3 \mathrm{H}$, q, flur. $\left.\mathrm{CH}_{3}\right), 3.74$ and $4.57(1 \mathrm{H}, \mathrm{qq}$, flur. $\mathrm{CH}), 7.22-7.54(10 \mathrm{H}, \mathrm{m}$, Ar-H), 8.07 and 8.39 (1H, ss, CH=N), 11.49 and $11.67(1 \mathrm{H}, \mathrm{ss}, \mathrm{NH}$, $\mathrm{D}_{2} \mathrm{O}$ exchangeable). Anal. Calcd for $\mathrm{C}_{20} \mathrm{H}_{16} \mathrm{BrFN}_{2} \mathrm{OS}$ : C, 55.69; $\mathrm{H}$, 3.74; N, 6.49. Found: C, 55.90; H, 3.06; N, 6.58.

2-(2-fluorobiphenyl-4-yl)- $N^{\prime}$-(phenylmethylidene)propanehydrazide (3p)

Yield 93\%; m.p $190^{\circ} \mathrm{C}$; UV (MeOH) $\lambda_{\max }$ nm: 282, 251, 202; IR (cm-1): 3164 (N-H str of amide), 1645 (C=O str of amide), 1600 (C=N str of hydrazone); ${ }^{1} \mathrm{H}-\mathrm{NMR}\left(\mathrm{DMSO}_{6}, 400 \mathrm{MHz}\right) \delta$ (ppm): $1.45\left(3 \mathrm{H}, \mathrm{q}\right.$, flur. $\left.\mathrm{CH}_{3}\right), 3.78$ and $4.77(1 \mathrm{H}, \mathrm{qq}$, flur. $\mathrm{CH})$, 7.28-7.70 (13H, m, Ar-H), 7.96 and $8.22(1 \mathrm{H}, \mathrm{ss}, \mathrm{CH}=\mathrm{N}), 11.40$ and $11.60(1 \mathrm{H}, \mathrm{ss}, \mathrm{NH})$. Anal. Calcd for $\mathrm{C}_{22} \mathrm{H}_{19} \mathrm{FN}_{2} \mathrm{O}$ : C, 76.28; H, 5.53; N, 8.09. Found: C, 75.94; H, 5.45; N, 8.09. 
$N^{\prime}$-[(2,4-dinitrophenyl)methylidene]-2-(2-fluorobiphenyl4-yl)propanehydrazide (3r)

Yield 88\%; m.p 150-152 ${ }^{\circ} \mathrm{C}$; UV (MeOH) $\lambda_{\max }$ nm: 335, 244, 202; IR ( $\left.\mathrm{cm}^{-1}\right)$ : 3198 (N-H str of amide), 1660 (C=O str of amide), 1600 (C=N str of hydrazone); ${ }^{1} \mathrm{H}-\mathrm{NMR}$ (DMSO- $\mathrm{d}_{6}$, $400 \mathrm{MHz}) \delta(\mathrm{ppm}): 1.47\left(3 \mathrm{H}, \mathrm{q}\right.$, flur. $\left.\mathrm{CH}_{3}\right), 3.83$ and $4.76(1 \mathrm{H}$, qq, flur. $\mathrm{CH}), 7.27-8.58(11 \mathrm{H}, \mathrm{m}, \mathrm{Ar}-\mathrm{H}), 8.68$ and 8.77 (1H, ss, $\mathrm{CH}=\mathrm{N}), 11.95$ and $12.18(1 \mathrm{H}, \mathrm{ss}, \mathrm{NH})$. Anal. Calcd for $\mathrm{C}_{22} \mathrm{H}_{17} \mathrm{FN}_{4} \mathrm{O}_{5}$ : C, 60.55; H, 3.93; N, 12.84. Found: C, 60.18; H, $3.80 ; \mathrm{N}, 12.75$.

$N^{\prime}$-[(2-chloro-6-fluorophenyl)methylidene]-2-(2-fluorobiphenyl-4-yl)propanehydrazide (3s)

Yield 97\%; m.p $171^{\circ} \mathrm{C}$; UV (MeOH) $\lambda_{\max } \mathrm{nm}: 282,251$; IR $\left(\mathrm{cm}^{-}\right.$ 1): 3184 (N-H str of amide), 1660 (C=O str of amide), 1622 (C=N str of hydrazone); ${ }^{1} \mathrm{H}-\mathrm{NMR}$ (DMSO-d $\left.{ }_{6}, 400 \mathrm{MHz}\right) \delta$ (ppm): $1.44\left(3 \mathrm{H}, \mathrm{q}\right.$, flur. $\left.\mathrm{CH}_{3}\right), 3.78$ and $4.69(1 \mathrm{H}, \mathrm{qq}$, flur. $\mathrm{CH}), 7.22-$ $7.53(11 \mathrm{H}, \mathrm{m}, \mathrm{Ar}-\mathrm{H}), 8.26$ and $8.45(1 \mathrm{H}, \mathrm{ss}, \mathrm{CH}=\mathrm{N}), 11.62$ and 11.80 (1H, ss, NH); EI-MS (m/z, \%): $401\left(\mathrm{M}^{+2}, 35.6\right), 400\left(\mathrm{M}^{+1}\right.$, 26.1), 399 (M+1 100), 383 (1.0), 381 (1.5), 286 (4.1), 270 (1.6), 154 (2.3), 137 (2.3). Anal. Calcd for $\mathrm{C}_{22} \mathrm{H}_{17} \mathrm{ClF}_{2} \mathrm{~N}_{2} \mathrm{O}: \mathrm{C}, 66.25 ; \mathrm{H}$, 4.30; N, 7.02. Found: C, 66.54; H, 4.29; N, 7.06.

$N^{\prime}$-[(4-trifluoromethoxyphenyl)methylidene]-2-(2-fluorobiphenyl-4-yl)propanehydrazide (3t)

Yield 89\%; m.p $164^{\circ} \mathrm{C}$; UV (MeOH) $\lambda_{\max }$ nm: 282, 251 ; IR (cm1): 3338 (N-H str of amide), 1672 (C=O str of amide), 1618 (C=N str of hydrazone); ${ }^{1} \mathrm{H}-\mathrm{NMR}$ (DMSO-d $\left.{ }_{6}, 400 \mathrm{MHz}\right) \delta$ (ppm): $1.06\left(3 \mathrm{H}, \mathrm{q}\right.$, flur. $\left.\mathrm{CH}_{3}\right), 1.46\left(3 \mathrm{H}, \mathrm{t}\right.$, ethanol $\left.-\mathrm{CH}_{3}\right), 3.45(2 \mathrm{H}, \mathrm{m}$, ethanol $\left.-\mathrm{CH}_{2}\right), 3.80$ and $4.78(1 \mathrm{H}, \mathrm{qq}$, flur. $\mathrm{CH}), 4.35(1 \mathrm{H}, \mathrm{q}$, ethanol -OH), 7.27-7.93 (12H, m, Ar-H), 8.03 and $8.29(1 \mathrm{H}$, ss, $\mathrm{CH}=\mathrm{N}), 11.57$ and $11.78(1 \mathrm{H}, \mathrm{ss}, \mathrm{NH})$. Anal. Calcd for: $\mathrm{C}_{23} \mathrm{H}_{18} \mathrm{~F}_{4} \mathrm{~N}_{2} \mathrm{O}_{2} .{ }^{1 / 2} \mathrm{C}_{2} \mathrm{H}_{5} \mathrm{OH} \mathrm{C}, 63.57 ; \mathrm{H}, 4.66 ; \mathrm{N}, 6.17$. Found: $\mathrm{C}$, 64.24; H, 4.49; N, 6.28.

2-(2-fluorobiphenyl-4-yl)- $N^{\prime}-[(2-h y d r o x y p h e n y l)$ methylidene]propanehydrazide $(3 \mathrm{u})$

Yield 99\%; m.p 169C; UV (MeOH) $1_{\max }$ nm: 290, 284, 249; IR ( $\left.\mathrm{cm}^{-1}\right)$ : 3223 (O-H str of phenol), 3078 (N-H str of amide), 1685 (C=O str of amide), 1620 ( $\mathrm{C}=\mathrm{N}$ str of hydrazone); ${ }^{1} \mathrm{H}-\mathrm{NMR}$ $\left(\mathrm{DMSO}_{6} \mathrm{~d}_{6}, 400 \delta \mathrm{MHz}\right) \mathrm{d}(\mathrm{ppm}): 1.35\left(3 \mathrm{H}, \mathrm{t}\right.$, flur. $\left.\mathrm{CH}_{3}\right), 3.68$ and 4.59 (1H, qq, flur. $\mathrm{CH}), 6.77-7.45(12 \mathrm{H}, \mathrm{m}, \mathrm{Ar}-\mathrm{H}), 8.16$ and 8.32 $(1 \mathrm{H}, \mathrm{ss}, \mathrm{CH}=\mathrm{N}), 10.61$ and $11.45(1 \mathrm{H}, \mathrm{ss}, \mathrm{NH}), 12.17(1 \mathrm{H}, \mathrm{s}$, phenol -OH). Anal. Calcd for: $\mathrm{C}_{22} \mathrm{H}_{19} \mathrm{FN}_{2} \mathrm{O}_{2} \mathrm{C}, 72.91 ; \mathrm{H}, 5.28 ; \mathrm{N}$, 7.73. Found: C, 72.90; H, 5.23; N, 7.73.

\section{Biological Activity}

Cancer cell growth inhibitory assay

The cytotoxic and/or growth inhibitory effects of the compounds were tested in vitro at a single dose $(10 \mu \mathrm{M})$ against the full panel of 60 human tumor cell lines derived from nine neoplastic diseases (20-22).

\section{HCV NS5B Polymerase Inhibitory Activity}

All synthesized compounds were evaluated for inhibition of hepatitis C virus NS5B RNA dependent RNA polymerase activity in primer dependent elongation assays as previously described (23-25). Activity of NS5B in the presence of equivalent amounts of DMSO was set at $100 \%$ and that in the presence of the inhibitor was calculated relative to this control.

\section{Molecular Modeling}

Ligand Structure Preparation

Compound $3 \mathrm{~m}$ was built, using the fragment dictionary of Maestro 9.0 and energy minimized by Macromodel program v9.7 (Schrödinger, Inc., New York, NY, 2009). The low-energy $3 \mathrm{D}$ structures of compound $3 \mathrm{~m}$ were generated with the following parameters present in LigPrep v2.3: different protonation states at physiological $\mathrm{pH}$, all possible tautomers, ring conformations and stereoisomers. The output obtained from the LigPrep run was used as input for docking simulations.

\section{Protein Structure Preparation}

The X-ray co-crystal structures of MK-3281-NS5B-thumb pocket (TP)-I (PDB ID: 2XWY) (26), PF-00868554-NS5B-TP-II (PDB ID: 3FRZ) (27), SB698223-NS5B-palm pocket (PP)-I (PDB ID: 2JC1) (28), HCV-796-NS5B-PP-II (PDB ID: 3FQL) (29), obtained from the RCSB protein data bank were energy-minimized according to the protein preparation tool present in Maestro. These co-crystal structures were then used for generating the grids around respective bound ligands. Additionally we have also generated a grid for PP-III pocket using HCV-796 bound structure with extended grid dimensions.

\section{Docking Protocol}

The "Extra Precision" (XP) mode of Glide program v5.0 (Schrödinger, Inc., New York, NY, 2009) and the default parameters were used during the docking protocol. The top scoring compound $3 \mathrm{~m}$ pose-NS5B complex was further subjected to energy minimization using Macromodel program v9.7 with the OPLS-AA force field and used for graphical analysis. All computations were carried out on a Dell Precision 470n dual processor with the Linux OS (Red Hat Enterprise WS 4.0).

\section{RESULTS AND DISCUSSION}

\section{Synthesis of Flurbiprofen hydrazide-hydrazones}

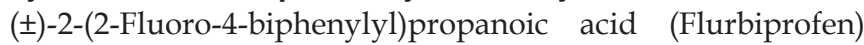
was chosen as the starting compound to design several novel hydrazide-hydrazones. Methyl 2-(2-fluorobiphenyl-4-yl)propanoate 1 was prepared by the reaction of flurbiprofen and methanol in the presence of a few drops of concentrated sulfuric acid. The reaction of compound 1 with hydrazine-hydrate in methanol resulted in 2-(2-fluorobiphenyl-4-yl)propanoic acid hydrazide 2 (19). Compound 2 was condensed with substituted aldehydes in ethanolic medium employing microwave assisted synthesis to obtain new 2-(2-fluorobiphenyl4-yl)-[(nonsubstituted/substituted furyl/phenyl/pyridyl/ thienyl)methylidene]propanehydrazides 3a-u (Figure 1).

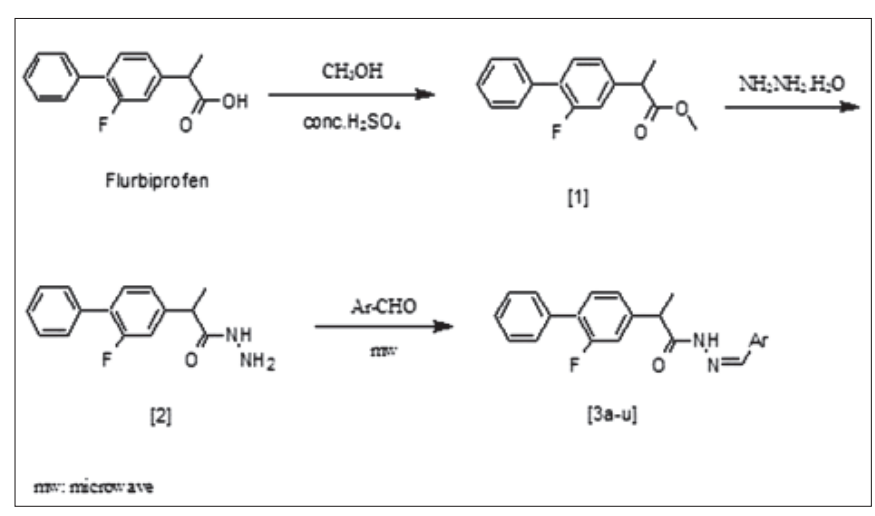

FIGURE 1. Synthesis of flurbiprofen hydrazide-hydrazones. 
The structures of compounds 3a-u were confirmed by elemental analyses and spectrometry techniques such as UV, IR, ${ }^{1} \mathrm{H}$ NMR, ${ }^{13}$ C NMR (only 31) and EI-mass (only 3s) and single crystal X-ray analysis (only 3s).

The hydrazones may exist as $Z / E$ geometrical isomers about $C=N$ double bonds and cis/trans amide isomers (30). In ${ }^{1} \mathrm{H}-\mathrm{NMR}$ spectra of compounds $3 \mathbf{a}-\mathbf{u}$, displayed the resonance of hydrazone $\mathrm{N}-\mathrm{H}$ at 10.61-12.18 ppm. Azomethine protons of compounds resonated at 7.76-8.68 ppm in $E$ isomer and at 8.00-8.77 in $Z$ isomer when recorded in dimethyl- $\mathrm{d}_{6}$ sulfoxide solvent. Also, methyne $\left(\mathrm{C} \underline{\mathrm{H}}-\mathrm{CH}_{3}\right)$ proton of flurbiprofen was observed as two quartets due to the canonic form. In addition, $-\mathrm{NH}$ proton of compound 30 was observed to exchange with $\mathrm{D}_{2} \mathrm{O}$ in the spectrum.

The ${ }^{13} \mathrm{C}-\mathrm{NMR}$ data of selected prototype $\mathbf{3 1}$ was found to be similar because of two possible geometric and rotational forms. The signals belonging to $-\mathrm{C}=\mathrm{O}$ group, $\mathrm{CH}_{3}$ group and $\mathrm{N}=\mathrm{CH}$ group derived from each cis-trans isomers were recorded at 174.77 and 169.73 ppm, 18.72 and 18.35 ppm, 149.64 and 149.56 ppm $(31,32)$, respectively.

EI-mass spectra of selected compound 3s displayed molecular ion peak at $\mathrm{m} / \mathrm{z}$ 399. The major fragmentation pathway appeared by the cleavage of $\mathrm{CONHN}=\mathrm{CH}$ bonds of amide moiety (Figure 2).

\section{Metrics of Green Chemistry}

The metrics of Green Chemistry were evaluated with $\mathbf{3 0}$ as the prototype compound. Compound 30 was synthesized by both conventional and the microwave assisted process. While the conventional method exhibited an overall yield of $49.00 \%$, microwave irradiation resulted in $84.00 \%$ yield, $35.00 \%$ increase (Table 1). Microwave irradiation assisted synthesis dramatically improved multiple parameters including a 24-fold reduction in time, $46.45 \%$ reduction in environmental factor, $33.55 \%$ increase in atom efficiency, $34.01 \%$ increase in carbon efficiency and $32.19 \%$ increase in reaction mass efficiency (Table 1). Together, this data strongly supports the use of microwave assisted technique as an excellent approach for rapid, inexpensive, simple and green method synthesis of medicinally important hydrazide-hydrazones. Calculation of these values was performed using green metrics evaluation (33). As green metrics evaluation with the representative compound (3o) clearly proved the advantages of microwave heating, this procedure was preferred in the synthesis of all remaining compounds.

\section{Determination of X-ray structure of 3s}

The X-ray structure of $3 \mathrm{~s}$ was determined in order to confirm the assigned structures and to establish conformations of the molecule. Table 2 summarizes the crystal and experimental data. Selected bond lengths and angles are listed in Table 3. The molecular structure of $3 \mathrm{~s}$ is shown in Figures 3 and 4 . Bond

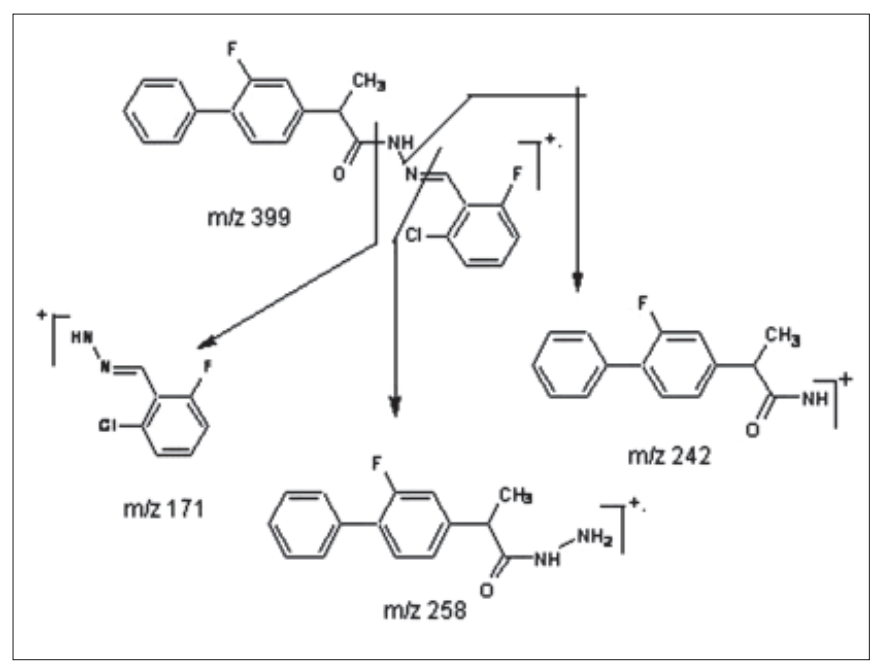

FIGURE 2. Common fragmentation pathway for the compounds 3s.

lengths and angles have normal values. Molecular conformation is stabilized by a weak intramolecular $\mathrm{C}-\mathrm{H}$... Cl hydrogen bond. The crystal structure is also stabilized by intermolecular $\mathrm{N}-\mathrm{H}$...O, C-H...F hydrogen bonding (Tables 2 and 3,) and $\mathrm{C}-\mathrm{H} . . . \pi$ interactions involve the (C1-C6) ring. The aromatic rings are essentially planar, with the maximum deviation from planarity being 0.010 (2) $\AA$ for atom C1 in the (C1-C6) ring, 0.013(2) $\AA$ for atom C7 in the (C7-C12) ring and -0.019 (2) $\AA$ for atom C17 in the (C17-C22) ring. The benzene ring (C17-C22) forms dihedral angles of $69.69(12)^{\circ}$ and $75.49(13)^{\circ}$ with (C1-C6) and (C7-C12) rings, respectively. Dihedral angle between the (C1-C6) and (C7-C12) rings is $48.32(10)^{\circ}$.

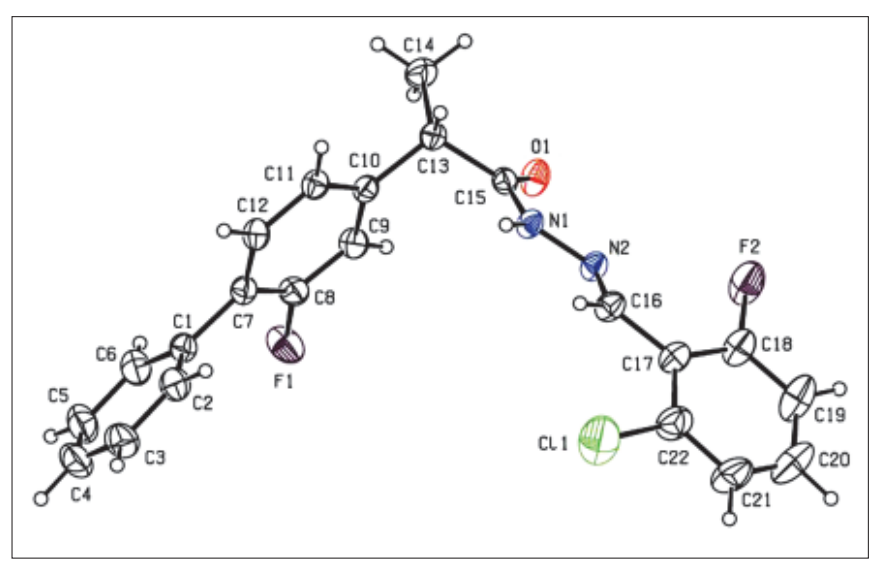

FIGURE 3. The molecule of the $3 s$, in the asymmetric unit, with the atom numbering scheme.Displacement ellipsoids for non-H atoms are drawn at the $30 \%$ probability level.

TABLE 1. Green chemistry metrics evaluation for compound 30

\begin{tabular}{lc}
\hline MATRIX & CONVENTIONAL \\
\hline Overall yield (\%) & 49.06 \\
Heating time & $120 \mathrm{~min}$ \\
E (environmental) factor (Kg waste/Kg product) & 31.050 \\
Atom efficiency (\%) & 47.09 \\
Carbon efficiency (\%) & 48.27 \\
Reaction mass efficiency (\%) & 45.20
\end{tabular}

\begin{tabular}{cc} 
GREEN TECHNIQUE & IMPROVEMENT \\
\hline 84.00 & $34.94 \%$ increase \\
5 min & 24 -fold decrease \\
4.648 & $85.03 \%$ reduction \\
80.64 & $33.55 \%$ increase \\
82.28 & $34.01 \%$ increase \\
77.39 & $32.19 \%$ increase
\end{tabular}




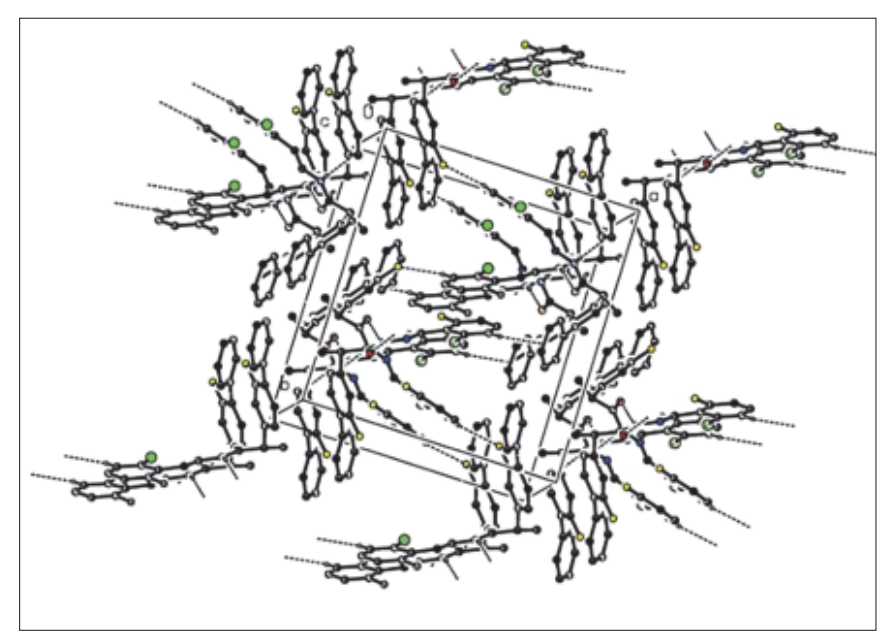

FIGURE 4. View of the packing and hydrogen bonding interactions of 3s. All hydrogen atoms not involved in hydrogen bonding have been omitted for clarity.

\begin{tabular}{lccc} 
TABLE 2. Geometric parameters of compound 3s $\left(\AA{ }^{\circ}\right)$ & \\
\hline C11-C22 & $1.726(3)$ & $\mathrm{N} 1-\mathrm{N} 2$ & $1.374(2)$ \\
F1-C8 & $1.363(2)$ & $\mathrm{N} 1-\mathrm{C} 15$ & $1.336(2)$ \\
F2-C18 & $1.358(3)$ & $\mathrm{N} 2-\mathrm{C} 16$ & $1.270(2)$ \\
O1-C15 & $1.223(2)$ & & \\
N2-N1-C15 & $120.44(14)$ & $\mathrm{O} 1-\mathrm{C} 15-\mathrm{C} 13$ & $122.41(16)$ \\
N1-N2-C16 & $113.91(15)$ & $\mathrm{N} 2-\mathrm{C} 16-\mathrm{C} 17$ & $121.95(17)$ \\
F1-C8-C9 & $117.22(15)$ & $\mathrm{F} 2-\mathrm{C} 18-\mathrm{C} 19$ & $117.0(2)$ \\
F1-C8-C7 & $118.81(17)$ & $\mathrm{F} 2-\mathrm{C} 18-\mathrm{C} 17$ & $118.85(19)$ \\
O1-C15-N1 & $123.26(16)$ & $\mathrm{Cl} 1-\mathrm{C} 22-\mathrm{C} 17$ & $119.41(18)$ \\
N1-C15-C13 & $114.33(14)$ & $\mathrm{Cl1}-\mathrm{C} 22-\mathrm{C} 21$ & $118.4(2)$
\end{tabular}

TABLE 3. Hydrogen-bond parameters of compound $3 s\left(\AA{ }^{\circ}{ }^{\circ}\right)$

\begin{tabular}{lcccc}
\hline & D-H & H...A & D...A & D-H...A \\
\hline N1-H1_..O1i & 0.86 & 2.07 & $2.856(2)$ & 152 \\
C16-H16...Cl1 & 0.93 & 2.68 & $3.012(2)$ & 102 \\
C21-H21...F1ii & 0.93 & 2.55 & $3.322(3)$ & 141 \\
C14-H14A...Cg1iii & 0.96 & 2.84 & $3.781(2)$ & 166 \\
C20-H20...Cg1ii & 0.93 & 2.74 & $3.559(3)$ & 147 \\
\hline
\end{tabular}

Symmetry codes: (i) $x, 3 / 2-y, 1 / 2+z$; (ii) $1-x, 1 / 2+y, 1 / 2-z$; (iii) $-x, 1-y, 1-z$.

\section{Biological Activity}

As most of the compounds in the series of structures submitted include one or more functional groups that have been found troublesome to the development of successful drug candidates, only compounds $3 p$ and 3 s were selected by the National Cancer Institute (NCI) for screening of their anticancer potential. In addition, the selection criteria guidance is available online at the DTP web site (http://www. dtp.nci.nih.gov/docs/misc/common_files/guidelines. html) (34).

The cell lines used in the NCI screen were leukemia, non-small cell lung cancer (NSCL), colon cancer, central nervous system (CNS) cancer, melanoma, ovarian cancer, renal cancer, prostate cancer and breast cancer cell lines (20-22). Compound 3p inhibited the growth of a leukemia cancer cell line HL-60 (TB) by $66.37 \%$ at $10 \mu \mathrm{M}$. Compound 3 s inhibited the growth of an ovarian cancer cell line OVCAR-4 by $77.34 \%$. Since both these compounds reduced the growth of the test cell lines by $\geq 32 \%$, they were considered as active and further evaluated against the complete panel of 60 cell lines at $10 \mu \mathrm{M}$ concentration. However, neither compound had significant activity against the 60 human tumor cell lines.

We next examined the anti-HCV NS5B RdRp inhibitory activty of these newly synthesized flurbiprofen hydrazide-hydrazone derivatives 3a-u. As shown in Table 4, the compounds exhibited inhibition of NS5B RdRp activity ranging from 7.0 to $60.0 \%$ at $200 \mu \mathrm{M}$ concentration. Some of flurbiprofen hydrazones were found to be more potent than flurbiprofen $(23.3 \%$, $200 \mu \mathrm{M})$ in this investigation. Compound $3 \mathrm{~m}$ was observed to be the most active of the derivatives tested. Therefore, we investigated the potential binding mode of compound $3 \mathrm{~m}$ to HCV NS5B.

TABLE 4. Anti-HCV NS5B RdRp activity of compounds 3a-u.

\begin{tabular}{lccc}
$\begin{array}{l}\text { Comp. } \\
\text { (Lab.Code No) }\end{array}$ & \% Inhibitiona & $\begin{array}{c}\text { Comp. } \\
\text { (Lab.Code No) }\end{array}$ & \% Inhibitiona \\
\hline 3a (SGK-289) & $27.2 \pm 4.2$ & 3k (SGK-299) & $22.0 \pm 3.5$ \\
3b (SGK-290) & $33.9 \pm 1.3$ & 3l (SGK-300) & $53.6 \pm 3.5$ \\
3c (SGK-291) & $39.3 \pm 2.2$ & 3m (SGK-301) & $59.5 \pm 0.5$ \\
3d (SGK-292) & $37.5 \pm 4.1$ & 3n (SGK-302) & $39.2 \pm 5.8$ \\
3e (SGK-293) & $9.7 \pm 2.2$ & 3o (SGK-303) & $50.3 \pm 4.3$ \\
3f (SGK-294) & $41.7 \pm 0.6$ & 3p (SGK-304) & $12.4 \pm 2.2$ \\
3g (SGK-295) & $28.6 \pm 3.2$ & 3r (SGK-305) & $6.9 \pm 5.0$ \\
3h (SGK-296) & $17.9 \pm 1.2$ & 3s (SGK-306) & $16.5 \pm 5.2$ \\
3i (SGK-297) & $19.9 \pm 5.1$ & 3t (SGK-307) & $34.6 \pm 5.1$ \\
3j (SGK-298) & $7.0 \pm 0.2$ & 3u (SGK-308) & $53.6 \pm 4.0$ \\
& & Flurbiprofen & 23.3
\end{tabular}

aPercent inhibition was determined at $200 \mu \mathrm{M}$ concentration of the indicated compound and represents an average of at least two independent measurements in duplicate.

\section{Binding mode of compound $3 \mathrm{~m}$ within the AP-B of NS5B}

To investigate the potential binding mode of compound $3 \mathrm{~m}$ to HCV NS5B, we performed molecular docking and our choice of $3 \mathrm{~m}$ for docking study was based on its high activity as well as it serves as a representative of active aryl/heteroarylmethylidene analogs $3 \mathbf{1}, \mathbf{3 o}$ and $3 \mathbf{u}$. Towards this end, we first examined the binding scores of compound $3 \mathrm{~m}$ in the five reported NS5B allosteric sites, such as Thumb pocket(TP)-I (PDB ID: 2XWY) (26), TP-II (PDB ID: 3FRZ) (27), Palm pocket (PP)-I (PDB ID: 2JC1) (28), PP-II (PDB ID: 3FQL) (29), and PP-III, that significantly overlaps with PP-II (large grid box created around HCV-796 coordinates, with the objective of identifying the NS5B allosteric pocket to which compound $3 \mathrm{~m}$ potentially binds. The binding energy (XP-Glide score) of (S)-isomer of compound $3 \mathrm{~m}$ was found to be more negative than the corresponding $(R)$-isomer and moreover the relatively more negative XP-Glidescore in AP-B versus other pockets indicated a better fit of $(S)$-compound $3 \mathrm{~m}$ in AP-B, thus suggesting that AP-B may be the potential binding site for flurbiprofen-hydrazide derivatives.

To understand the intermolecular interactions, we analyzed the docked conformation of compound $3 \mathrm{~m}$ within AP-B of NS5B (Figure 5). As shown in Figure 5, the orthofluorobiphenyl moiety was found to participate in extensive hydrophobic interactions with Leu419, Met423, Ile482, 


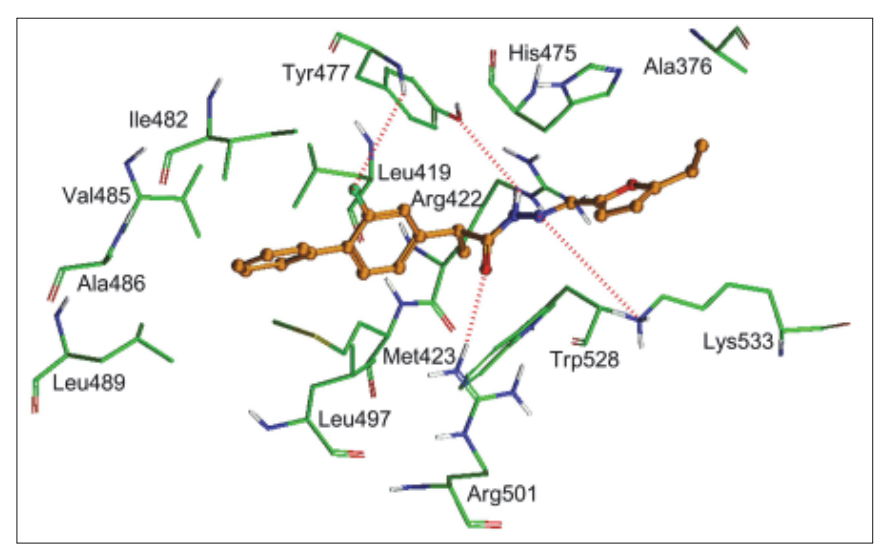

FIGURE 5. XP-Glide predicted binding mode of compound $3 m$ (SGK-301) within AP-B of NS5B. Important amino acids contacting compound 3m (SGK-301) are depicted as stick model with the atoms colored as carbon - green, hydrogen white, nitrogen - blue, oxygen - red and sulfur - yellow. Compound 3m (SGK-301) is shown as ball and stick model with the same color scheme as above except carbon atoms are represented in orange and the fluoro in green. The dashed red lines indicate dipole-dipole interactions.

Val485, Ala486, Leu489, and Leu497. The propane-hydrazide moiety is stabilized through a series of dipole-dipole interactions with the side chain of Arg422, Arg501, and Lys533 as depicted in dashed red lines. The furan ring is mainly stabilized through hydrophobic interaction with Ala476 and the methylene groups of Lys533 and aromaticaromatic interactions with the imidazole ring of His475 and the indole ring of Trp528. The furan ring oxygen atom may form a dipole-dipole interaction with the guanidine group of Arg422. Thus, binding mode of compound 3m indicates that the terminal phenyl ring of the biphenyl moiety can be substituted with small hydrophobic groups such as methyl, ethyl, isopropyl etc, and participate through extensive hydrophobic interactions. Moreover, the ethyl substituted furan-2-yl ring can be replaced with benzofuran-2-yl to pick up cation-pi type of interaction between the face of the phenyl portion of the benzofuran ring and side chain amino group of Lys533.

\section{CONCLUSION}

In summary, twenty new flurbiprofen hydrazide-hydrazones were synthesized by microwave assisted reactions and prototype compound 3o was synthesized in higher yields, in faster time, and with less chemical waste compared to traditional techniques. Two compounds $3 p$ and $3 s$ inhibited the growth of a leukemia cancer cell line HL-60 (TB) and an ovarian cancer cell line OVCAR-4, respectively, at $10 \mu \mathrm{M}$, but had no significant effect on a panel of sixty human tumor cell lines. Although the compounds were found to exhibit weak inhibition of $\mathrm{HCV}$ NS5B polymerase activity, molecular docking and binding mode investigations suggested potential chemical modifications to improve the potency of the S-flurbiprofen hydrazidehydrazones.

\section{ACKNOWLEDGEMENTS}

We thank the Division of Cancer Research, National Cancer Institute, Bethesda, MD, for the anticancer activity screening.This work was supported by The Scientific and Technical Research Council of Turkey (TÜBITAK), Research Fund Project Number: SBAG-HYD-339 (108S257) to S.G.K. HCV NS5B inhibition studies were supported by the National Institute of Health Research Grant CA153147 to N.K.-B.. Flurbiprofen was supplied by Sanovel Pharmaceutical Industry Inc.

\section{Anti-HCV NS5B ve antikanser ajanı olarak bazı yeni flurbiprofen hidrazit-hidrazonlarının mikrodalga destekli sentezi}

ÖZET: Mikrodalga destekli reaksiyon kullanılarak bir dizi yeni flurbiprofen hidrazit-hidrazonlar sentezlenmiştir. Flurbiprofen hidraziti ve sübstitüe aldehitlerin mikrodalga ışınımı ile muamelesi sonucu hidrazonlar elde edilmiştir. Mikrodalga yöntemi ile sentezlenen N'-[(4-bromotiyofen-2-il)metiliden]-2-(2-fluorobifenil-4-il)-propanhidrazit (3o) bileşiği konvensiyonel yönteme kıyasla daha yüksek verim, daha az zaman ve atık açısından daha az kimyasal kullanılarak elde edilmiştir. 2-(2-fluorobifenil-4-il)-N'-(fenilmetiliden)propanhidrazit (3p) ve N'-[(2-kloro-6-fluorofenil)metiliden]-2(2-fluorobifenil-4-il)propanhidrazit (3s) bileşikleri National Cancer Institute (NCI) tarafından HL-60 (TB) lösemi kanser hücresinde \% 66.37 ve OVCAR-4 yumurtalık kanser hücresinde \% 77.34 (tek doz, $10 \mu \mathrm{M}$ ) büyüme inhibisyonu sağlamış, ancak altmış adet insan tümör hücre hattı üzerinde anlamlı bir etki görülmemiştir. Ayrıca, Flurbiprofen hidrazithidrazonları HCV-NS5B enzim aktivitesini zayıf derecede inhibe etmiş, N'-[(5-etilfuran-2-il)metiliden]-2-(2-fluorobifenil4-il)propanhidrazit $(3 \mathrm{~m})$ bileşiği bu serinin en etkili bileşiği olarak tespit edilmiştir. Bileşik 3m'nin enzime bağlanma bölgeleri incelendiğinde, (AP)-B allosterik cebinin flurbiprofen hidrazonları için potansiyel bağlanma bölgesi olabileceği düşünülmüş, dolayısıyla yeşil kimya yaklaşımı kullanarak $3 \mathrm{~m}$ bileşiğinin türevlendirilmesi ve etkin olan $S$-flurbiprofen hidrazit-hidrazonların geliştirilmesi sonucu ortaya çıkmıştır.

ANAHTAR SÖZCÜKLER: Antikanser aktivite, E-Z isomerizm, Flurbiprofen, Hepatit C NS5B polimeraz, Hidrazit-hidrazon, Mikrodalga. 


\section{REFERENCES}

1. Tseng LL, Cheng HH, Huang CJ, Liu SI, Kuo CC, Chen WC, Huangm JK, Hsu SS, Chang HT, Kao CH, Ho CM, Jan CR. Dual effect of flurbiprofen on cell proliferation and agonist-induced $\mathrm{Ca}(2+)$ movement in human osteosarcoma cells. Basic Clin Pharmacol Toxicol 2006; 98 : 160-7.

2. Jin $H$, Wang $Z$, Liu L, Gao L, Sun $L$, Li $X$, Zhao $H$, Pan Y, Shi H, Liu N, Hong L, Liang J, Wu Q, Yang Z, Wu $\mathrm{K}$, Fan D. R-flurbiprofen reverses multidrug resistance, proliferation and metastasis in gastric cancer cells by p75(NTR) induction. Mol Pharm 2010; 7: 156-68.

3. Wechter WJ, Kantoci D, Murray Jr ED, Quiggle DD, Leipold DD, Gibson KM, McCracken JD. R-flurbiprofen chemoprevention and treatment of intestinal adenomas in the APC(Min)/+ mouse model: implications for prophylaxis and treatment of colon cancer. Cancer Res 1997; 57: 4316-24.

4. Wechter WJ, Leipold DD, Murray Jr ED, Quiggle D, McCracken JD, Barrios RS, Greenberg NM. E-7869 (R-flurbiprofen) inhibits progression of prostate cancer in the TRAMP mouse. Cancer Res 2000; 60: 2203-8.

5. Wechter WJ, Murray Jr ED, Kantoci D, Quiggle DD, Leipold DD, Gibson KM, McCracken JD. Treatment and survival study in the C57BL/6J-APC(Min)/+(Min) mouse with R-flurbiprofen. Life Sci 2000; 66: 745-53.

6. Grosch S, Tegeder I, Schilling K, Maier TJ, Niederberger E, Geisslinger G. Activation of c-Jun-N-terminal-kinase is crucial for the induction of a cell cycle arrest in human colon carcinoma cells caused by flurbiprofen enantiomers. FASEB J 2003; 17: 1316-8.

7. Rollas $S$, Küçükgüzel ŞG. Biological activities of hydrazone derivatives. Molecules 2007; 12: 1910-39.

8. Koçyiğit-Kaymakçığlu B, Oruç E, Ünsalan S, Kandemirli F, Shvets N, Rollas S, Anatholy D. Synthesis and characterization of novel hydrazide-hydrazones and the study of their structure-antituberculosis activity. Eur J Med Chem 2006; 41: 1253-61.

9. Gürsoy E, Ulusoy Güzeldemirci N. Synthesis and primary cytotoxicity evaluation of new imidazo[2,1-b]thiazole derivatives. Eur J Med Chem 2007; 42: 320-6.

10. Özdemir A, Kaplancıklı ZA, Turan-Zitouni1 G, Revial G. Synthesis of some novel hydrazone derivatives and evaluation of their antituberculosis activity. Marmara Pharm J 2010; 14: 79-83.

11. Tatar E, Çıkla $P$, Küçükgüzel ŞG, Küçükgüzel İ, Şahin F, Yurdakul D, Kaushik-Basu N, Krishnan R. Synthesis and biological activity of ( \pm )-2-(2-Fluoro-4-biphenylyl) propanoic acid hydrazide derivatives. Third International Meeting on Pharmacy \& Pharmaceutical Sciences, İstanbul-TURKEY, June 9-12, 2010; p. 98.

12. Gedye $R N$, Smith FE, Westaway $K C$. The rapid synthesis of organic compounds in microwave ovens. Can J Chem 1988; 66: 17-26.

13. Santagada V, Frecentese F, Perissutti E, Favretto L, Caliendo G. The Application of Microwaves in Combinatorial and High-Throughput Synthesis as New Synthetic Procedure in Drug Discovery. QSAR Comb Sci 2004; 23: 919-44.

14. Stoe \& Cie $X$-AREA and $X-R E D 32$. Stoe \& Cie, Darmstadt, Germany, 2002.
15. Altomare A, Burla MC, Camalli M, Cascarano GL, Giacovazzo C, Guagliardi A, Moliterni AGG, Polidori G, Spagna RJ. SIR97: A new tool for crystal structure determination and refinement. Appl Cryst 1999; 32: 115-9.

16. Sheldrick GM. A short history of SHELX. Acta Cryst 2008; A64: 112-22.

17. Farrugia LJ. ORTEP-3 for Windows - a version of ORTEPIII with a Graphical User Interface (GUI). J Appl Cryst 1997; 30: 565.

18. Farrugia LJ. WinGX suite for small-molecule single-crystal crystallography. J Appl Cryst 1999; 32:837-8.

19. Amir M, Kumar S. Synthesis of some new 2-(2-fluoro4-biphenylyl)propionic acid derivatives as potential anti-inflammatory agents. Pharmazie 2005; 60: 175-80.

20. Alley MC, Scudiero DA, Monks PA, Hursey ML, Czerwinski MJ, Fine DL, Abbott BJ, Mayo JG, Shoemaker RH, Boyd MR. Feasibility of drug screening with panels of human tumor cell lines using a microculture tetrazolium assay. Cancer Res 1988; 48: 589-601.

21. Grever MR, Schepartz SA, Chabner BA. Cancer drug discovery and development program. Semin Oncol 1992; 19: 622-38.

22. Boyd MR, Paul KD. Some practical considerations and applications of The Nationa Cancer Institute in vitro anticancer drug discovery screen. Drug Dev Res 1995: 34; 91-109.

23. Chen $Y$, Bopda-Waffo A, Basu A, Krishnan R, Silberstein E, Taylor DR, Talele TT, Arora P, Kaushik-Basu N. Characterization of aurintricarboxylic acid as a potent hepatitis $C$ virus replicase inhibitor. Antivir Chem Chemother 2009; 20: 19-36.

24. Kaushik-Basu N, Bopda-Waffo A, Talele TT, Basu A, Chen Y, Küçükgüzel ŞG. 4-Thiazolidinones: a novel class of hepatitis C virus NS5B polymerase inhibitors. Front Biosci 2008; 13: 3857-68.

25. Kaushik-Basu N, Bopda-Waffo A, Talele TT, Basu A, Costa PR, da Silva AJ, Sarafianos SG, Noel F. Identification and characterization of coumestans as novel HCV NS5B polymerase inhibitors. Nucleic Acids Res 2008; 36: 1482-96.

26. Narjes F, Crescenzi B, Ferrara $M$, Habermann J, Colarusso S, Ferreira Mdel R, Stansfield I, Mackay AC, Conte I, Ercolani C, Zaramella S, Palumbi MC, Meuleman P, Leroux-Roels G, Giuliano C, Fiore F, Di Marco S, Baiocco P, Koch U, Migliaccio G, Altamura S, Laufer R, De Francesco R, Rowley M. Discovery of (7R)-14-cyclohexyl-7-\{[2(dimethylamino)ethyl](methyl) amino\}-7,8-dihydro-6Hindolo[1,2-e][1,5]benzoxazocine-11-carboxylic acid (MK3281), a potent and orally bioavailable finger-loop inhibitor of the hepatitis C virus NS5B polymerase. J Med Chem 2011; 54: 289-301.

27. Li H, Tatlock J, Linton A, Gonzalez J, Jewell T, Patel L, Ludlum S, Drowns M, Rahavendran SV, Skor H, Hunter R, Shi ST, Herlihy KJ, Parge H, Hickey M, Yu X, Chau F, Nonomiya J, Lewis C. Discovery of (R)-6-cyclopentyl-6-(2-(2,6-diethylpyridin-4-yl)ethyl)-3-((5,7-dimethyl-[1,2,4] triazolo[1,5-a]pyrimidin-2-yl)methyl)-4-hydroxy-5,6-dihydropyran-2-one (PF-00868554) as a potent and orally available hepatitis $\mathrm{C}$ virus polymerase inhibitor. J Med Chem 2009; 52: 1255-8. 
28. Slater MJ, Amphlett EM, Andrews DM, Bravi G, Burton G, Cheasty AG, Corfield JA, Ellis MR, Fenwick RH, Fernandes S, Guidetti R, Haigh D, Hartley CD, Howes PD, Jackson DL, Jarvest RL, Lovegrove VL, Medhurst KJ, Parry NR, Price H, Shah P, Singh OM, Stocker R, Thommes P, Wilkinson C, Wonacott A. Optimization of novel acyl pyrrolidine inhibitors of hepatitis $C$ virus RNA-dependent RNA polymerase leading to a development candidate. J Med Chem 2007; 50: 897-900.

29. Hang JQ, Yang $Y$, Harris SF, Leveque $V$, Whittington $H J$, Rajyaguru S, Ao-Ieong G, McCown MF, Wong A, Giannetti AM, Le Pogam S, Talamas F, Cammack N, Najera I, Klumpp K. Slow binding inhibition and mechanism of resistance of non-nucleoside polymerase inhibitors of hepatitis C virus. J Biol Chem 2009; 284: 15517-29.

30. Rutavichyus A, Valiulene S, Kuodis Z. Synthesis and structure of hydrazones obtained from hydrazides of [5-(4-pyridyl)-1,3,4-oxadiazol-2-ylthio]acetic or 2-[5-(4-pyridyl)-1,3,4-oxadiazol-2-ylthio]propionic acids. Chem Heterocycl Compds 2000; 36:851-6.
31. Küçükgüzel ŞG, Mazi A, Şahin F, Öztürk S, Stables, J. Synthesis and biological activities of diflunisal hydrazide-hydrazones. Eur J Med Chem 2003; 38: 1005-13.

32. Küçükgüzel ŞG, Oruç EE, Rollas $S$, Şahin F, Özbek A. Synthesis, characterisation and biological activity of novel 4-thiazolidinones, 1,3,4-oxadiazoles and some related compounds. Eur J Med Chem 2002; 37: 197-206.

33. Constable DJC, Alan D, Cunningham $C$, Cunningham VL. Metrics to 'green' chemistry-which are the best? Green Chem 2002; 4: 521-7.

34. National Cancer Institute. Developmental Therapeutics Program: Screening Services Selection Guidelines for Small Molecule Structures for Screening. Accessed: 25 September 2012 